\title{
US biotechnology
}

\section{Living with regulation}

\section{Washington}

A SCORE of biotechnology companies received mixed signals when their representatives met here last week to discuss the regulatory outlook for their industry. Federal officials told them the government was not interested in "brazen overregulation" and Representative George Brown (Democrat, California) said biotechnology had many friends on Capitol Hill. But the companies were also warned that they will soon face a new group of regulatory hurdles and that the ultimate success of their industry depends on convincing the public of its safety.

The major focus of regulatory action in the coming months will be the Environmental Protection Agency (EPA), which has declared its intention under the Toxic Substances Control Act (TOSCA) to regulate the development of new genetically engineered substances. The agency's acting assistant administrator for pesticides and toxic substances, Don Clay, told industry leaders that EPA was making no presumption that recombinant DNA substances were toxic; they would be looked at in the same way as other substances. But he confirmed that EPA intends to exercise great caution before approving the release of recombinant microorganisms.

In an unwelcome echo of the lawsuit brought by environmental activists against the controversial frost-retardation experiment planned at the University of California, Berkeley (see Nature 13 October, p.564), Clay said it is possible that genetically engineered microorganisms may have adverse environmental consequences akin to those of the kudzu weed and the gypsy moth. EPA is therefore working on a set of questions that manufacturers will be required to resolve before the general release of such substances could be approved.

The list will include questions about the ability of organisms to survive under different conditions, to reproduce, to travel, to transfer genetic traits to natural organisms and to develop resistance against control agents. EPA would also want to know how the population of an engineered organism in the environment could be monitored and controlled. The questions will be published as guidelines early next year.

The meeting was convened by the Industrial Biotechnology Association (IBA), the fledgling consortium of companies set up in 1981 to promote the interests of the industry nationally. Privately, members of the association expressed doubts about EPA's competence in drawing up regulations for biotechnology products. While the Food and Drug Administration (FDA) received high marks, EPA was criticized for having too few scientists with strong credentials in biotechnology. Clay, however, told the meeting that EPA has started talks with other agencies to see whether it would be possible to pool the federal government's expertise in biotechnology regulation in a single interagency committee.

Representative George Brown told IBA that EPA's approach to biotechnology would be a "major decision point" for the industry because it would set the tone for other government agencies and deal with fundamental unresolved issues, such as the definition of genetically engineered organisms and "new" substances. Congress, he said, is unlikely to adopt legislation on biotechnology in the near future, but he advised IBA to act early to educate the public and eliminate the "more irrational" pressures on Congress.

A similar warning was delivered by

Nanette Newell, a member of the congressional Office of Technology Assessment and director of a forthcoming siudy of American competitiveness in biotechnology. Claiming that American industry is more liable than its competitors to suffer as a result of public perceptions, she urged IBA to step up its efforts to improve public understanding. The lawsuit brought by anti-DNA activist Jeremy Rifkin is an example of how a small number of people could generate a great deal of public concern, she said.

IBA itself is divided on how to deal with the Rifkin lawsuit. A proposal that the association submit an amicus brief on the side of the National Institutes of Health was rejected. One problem is that IBA still has fewer than 30 member companies and is short of funds. But some members are said to believe that it would be a mistake to transform a dispute between Rifkin and the federal government into a dispute in which the industry itself took too visible a part.

Peter David

\section{Information technology \\ Selling British software}

BOTH government and industry are urged to take better account of the value of tradeable information, in a report from the British Government's Information Technology Advisory Panel. The panel says that responsibilities in this area are "fragmented", as are the efforts of industrial companies, and proposes institutional changes to remedy the situation. Chief among these is the suggestion that a government minister should be appointed with overall responsibility in the area.

The panel's central thesis is that hardware advances are eroding traditional barriers between sectors of the information industry, defined by the panel as including everything from scientific publications to video entertainment. It complains that while government initiatives and industry's efforts have been devoted to hardware, opportunities in software development have been neglected.

But apart from this general exhortation, the panel makes few detailed recommendations. It stresses the need for more cooperation between companies and calls for interdepartmental government machinery to improve coordination. It fails to tackle the specifics of what it sees as the most important single task of government in the field: the speedy introduction of up-to-date copyright legislation.

The general message is nevertheless clear. Britain, according to the panel, has the potential to become a world leader in tradeable information, and the market is expected to grow rapidly. As things stand, however, there is no way of finding out whether or not Britain is a world leader, because there is an almost total lack of reliable information on information. The panel concludes that the lack of economic statistics on the tradeable information sector is a "grave defect".

The panel repeats the familiar comment that the main responsibility for development in the sector should rest with private industry, but also adds the equally familiar rider that there is much that government could do to facilitate the process. One major stimulus would be the publication of more government information in machinereadable form, which would encourage industry to set up suitable information networks. The means by which government receives information should also be kept under review to promote the widest possible use of machine-readable data. The panel identifies the provision of government support for the development of advanced software for searching databases as an important priority.

Tradeable information is not, however, to be reserved exclusively for hard-headed businessmen, and the panel would like to see the research councils sponsor further academic study of the economic potential in this field. The panel has a further note for those already active in supplying information, publishers of scientific journals included. They should, it says, examine their current activities closely - the development of scientific journals could before long start to limit the market for printed matter. Fortunately, perhaps, for those publishers, libraries do not yet commonly subscribe to electronic information networks, partly perhaps because of the cost. The slow take-up of British Telecom's Prestel system is attributed to a failure to recognize that the public will not pay simply for information which is at present free just because it is presented on a screen.

Tim Beardsley 